\title{
Effects of Utilitarian and Hedonic Emotion on the Use of Online Banking Services
}

\author{
Wei-Hsi Hung, National Chengchi University, Taiwan \\ (iD) https://orcid.org/0000-0002-8480-8079 \\ Chih-Lang Tseng, National Chung Cheng University, Taiwan \\ Fang-Kai Chang, Feng Chia University, Taiwan \\ (iD) https://orcid.org/0000-0001-8796-9751 \\ Chin-Fu Ho, Takming University of Science and Technology, Taiwan
}

\begin{abstract}
The online banking service is the key element for the development of e-commerce and e-businesses. It provides users with convenient daily transaction services, such as wire transfer and online payment. Past studies on online banking services mostly focused on their functionality, whereas little pay attention to users' hedonic feelings or a sense of pleasure. Besides, discussions about post-adoption behavior are also immature. Thus, this study aims to explore the impacts of customers' positive or negative experience of using online banking services on consumers' emotions. Furthermore, a discussion of post-adoption behaviors, including recommendations, complaints, and continuance intention is also provided. The result shows that positive user experience will have a significantly positive impact on the generation of utilitarian emotion. As for the sense of utilitarian emotion, users worry more about whether their goal could be achieved successfully via their operations or not, such as completing wire transfer transactions in the online banking environment.
\end{abstract}

\section{KEYWORDS}

Hedonic Emotions, Online Banking, Post-Adoption Behavior, User Experiences, Utilitarian Emotions

\section{INTRODUCTION}

Online banking was first originated in the period of the dot-com bubble about 20 years ago when 4,990 banks were offering or planning to offer full-service Internet banking in the United States (Pyun, Scruggs, \& Nam, 2002). Despite many players have closed down, the United Kingdom, Japan, China, and Hong Kong detonated the second wave of online banking due to the wave of financial technology (Xu, Tang, \& Guttman, 2019). Particularly, in places where financial infrastructure is insufficient, the demand for financial innovation is even greater. This is the tendency of the big environment which forces them to compete with traditional banks. For example, $80 \%$ of people in Africa do not have access to banking services or open accounts, but $93 \%$ have mobile devices. So, they directly use "online payment" from mobile phones to solve the problem of payment and remittance (Aker \& Mbiti, 2010).

The online banking is the key element for the development of electronic commerce and e-businesses. It provides users with convenient daily services, such as wire transfer and online payment

DOI: 10.4018/JGIM.20211101.oa5

This article published as an Open Access article distributed under the terms of the Creative Commons Attribution License (http://creativecommons.org/licenses/by/4.0/) which permits unrestricted use, distribution, and production in any medium, provided the author of the original work and original publication source are properly credited. 
for convenient transactions and time-saving for users (Zaffar, Kumar, \& Zhao, 2019). For banks, online banking technologies can enable higher service efficiency, save administrative costs, and provide borderless services. For consumers, these services are provided with no restrictions in terms of time and locality, which leads to reductions in time and costs. Online banking, therefore, is an imperative technology to retain key customers for banks under such intensified business competition nowadays (Laukkanen, 2016; Mbama, Ezepue, Alboul, \& Beer, 2018).

Traditionally, the development of online banking services has mainly focused on two dimensions: functionality and user interface (Ahmad \& Al-Zu'bi, 2011; Faroughian, Kalafatis, Ledden, Samouel, \& Tsogas, 2012; Rodrigues, Costa, \& Oliveira, 2016). Functionality refers to the financial service functions that online banking provides to customers. The user interface refers to the visual arrangement of presenting the above services to customers (Rodrigues et al., 2016). Both of these two dimensions can bring customers a direct sense of practicality and usability. With the popularization of online banking, a well-designed system has changed from a sufficient condition for successful online services to a necessary condition for successful services(Szopiński, 2016). While every bank proposes an online banking system with similar functions and interfaces, having good functions and interfaces has become a necessary condition, rather than a competitive advantage (Bradley \& Stewart, 2003).

In past studies, the determinations of the successful online banking and factors affecting the user acceptance of online banking have received much attention. The mainstream researches focus on the cognitive usability of online banking, which concerns usability, ease of use, and security issues (Durucu, Isik, \& Calisir, 2019; Hoehle, Scornavacca, \& Huff, 2012). However, only a few studies focused on customers' emotions in the banking industry that concern their satisfaction with the service (Mattila \& Enz, 2002; Reydet \& Carsana, 2017). Base on the Coherence Theory of Decision (CTD), people achieve a given goal through the interaction of cognition and emotion (Thagard, 2001; Thagard \& Millgram, 1997). This means that users' emotion and their interaction between users and online banking are equally important. For example, no matter how perfect the functions of online banking are, if people have a negative experience in the system, such as facing complex functions, cumbersome login authentication mechanisms, etc..., they will not continuously use the system as intended.

The importance of emotion research is that emotional factors not only affect individual behavior (Sun, Zhou, Jeyaraj, Shang, \& Hu, 2019), but also affect team performance (Sun, Wu, Chen, Lin, \& Shang, 2020), and even affect stock market trends (Sun, Liu, Chen, Hao, \& Zhang, 2020). In marketing research, customer emotions have gradually received more attention (Bagozzi, Gopinath, \& Nyer, 1999; Chaudhuri, 2006; Ladhari, Souiden, \& Dufour, 2017). Emotion is believed to play an important role in problem-solving, decision making, and marketing (Bagozzi et al., 1999), while the emotion of trustworthiness is regarded as one of the most crucial factors for a successful completion of business transactions (Kim \& Moon, 1998). Therefore, this study deems that users' emotional considerations will affect customers' expectations of continuance intention of online banking. These behavioral responses of customers will affect customer retention rates, deposit amounts, and the cost of providing services, and ultimately affect the bank's profitability (Marinkovic \& Obradovic, 2015).

This study aims to explore the impact of customers' positive or negative experience in using online banking services on consumers' emotions types. Recommendations, complaints, and continuance intention are also included. It particularly focused on testing the hypothesized relationships gathered from past studies, including whether positive emotions affect "recommendation" behavior, and negative emotions affect "complaining" behavior. More relationships, such as whether emotion affects satisfaction, and satisfaction affects users' continued use were also verified.

\section{LITERATURE REVIEW}

Technology acceptance is a popular topic studied in the field of user behavior. The frequently used models include the technology acceptance model, unified theory of acceptance and use of technology, etc. (Legris, Ingham, \& Collerette, 2003; Williams, Rana, \& Dwivedi, 2015). While the research 
focus in the field has been moved from behavioral intention to continuance intention, the factors that affect user adoption have been diversified. Moreover, user experience has become a crucial factor to influence post-adoption behavior (Castañeda, Muñoz-Leiva, \& Luque, 2007; Parthasarathy \& Bhattacherjee, 1998). Based on the CTD and Affective Events Theory (AET), the behavior is affected by the mutual interaction of cognitive and emotional factors, and the emotional response generated through the event experience will affect the overall satisfaction and subsequent behavioral response (Fisher, 2002; Thagard, 2001). Therefore, this research first reviews the related studies on online banking services in section 2.1. Section 2.2 focuses on the user experience after using a banking service. Then, section 2.3 reviews utilitarian and hedonic emotions. Finally, in section 2.4, various post-adoption behaviors are reviewed and discussed.

\subsection{Online Banking Service}

For many years, banks have been adopting the Internet as a channel to provide credit and deposit services through e-delivery technologies, such as mobile phones and computers (Asongu \& Nwachukwu, 2018; Shaikh \& Karjaluoto, 2015). Some studies focus on identifying factors that affect consumers' intentions to use online banking (Anouze \& Alamro, 2019; Montazemi \& Qahri-Saremi, 2015). Others tried to put forward factors that impact customer satisfaction from the online banking service quality and investigate the gap between consumer expectation and perception (LiébanaCabanillas, Muñoz-Leiva, \& Rejón-Guardia, 2013; Liébana-Cabanillas, Muñoz-Leiva, SánchezFernández, \& Viedma-del Jesús, 2016).

For research on the service quality of online banking, functionality quality and user interface design are mainly discussed (Ahmad \& Al-Zu'bi, 2011; Faroughian et al., 2012; Rodrigues et al., 2016). The quality of functionality can be subdivided into system quality and data quality (Ho \& Lin, 2010; Namahoot \& Laohavichien, 2015). System quality focuses on the system for online data access, which is known as the Web-System Online that can be accessed by users via browsers from their own access devices (Luo, Li, Zhang, \& Shim, 2010). Conversely, the data quality focuses on content richness, data correctness, etc. (Ho \& Lin, 2010; Rotimi, Awodele, \& Bamidele, 2007).

Regarding the user interface design of online banking services, the user-interactive interface refers to sensational reaction and stimulation caused by the visual and auditory scenes displayed on the user's screen via the interface design of the system (Rodrigues et al., 2016). It is an approach of webpage arrangement which can directly affect the mental feelings of users, such as aesthetic, thoughtful, comfortable, polite, etc. (al Afeef, Singh, \& Ahmad, 2012).

In general, either from the aspect of system and data quality or user interface design, online banking service must be convenient, including be able to access at any time and place through multiple service channels. The instructions should also be clear and easy to follow, while the procedures can be simply operated. Moreover, software and hardware requirements need to be clearly shown, and a broad range of services should be provided (Liao \& Cheung, 2002). Security, ease of use, interaction, navigability, and download speed must be concerned when designing online banking services (Ho $\&$ Lin, 2010; Shaikh \& Karjaluoto, 2015). For the above reasons, the quality of service provided by online banking would affect the user experience (Liébana-Cabanillas et al., 2016; Wang, Cho, \& Denton, 2017).

\subsection{User Experience After Using Banking Service}

User experience can be defined as a final result of the benefits obtained from consumption, which exists in the memory of the user and cannot be changed. (Holbrook, Lehmann, \& O'Shaughnessy, 1986). Consumers will compare the actual result with their expected goal and gaps, this form the user experience and will serve as a reference for a future transaction (Hornbæk \& Hertzum, 2017). When customers are making purchases, they will always recall experience to predict whether the product performance can achieve their expected goals, and then make choices based on these predicted results. After consumption, the product is evaluated to determine whether the expected performance 
conforms with the actual product performance (Oliver, 1977). Positive user experiences are generated when the expectation has been met, while negative experiences emerged when that has not been met (Chaudhuri, 2006; Kaasinen et al., 2015).

User experience leads to a positive or negative reaction of users (Nam, Baker, Ahmad, \& Goo, 2019; Pikkarainen, Pikkarainen, Karjaluoto, \& Pahnila, 2004), and this can be explained by the AET (Fisher, 2002). For example, if the performance of a product is better than or in consist with which expected by consumers, a positive experience is generated, and will eventually turn into a positive emotion. In contrast, if the product performance is worse than the customer's expectations, negative experience appears and turns into a negative emotion (Bagozzi et al., 1999; Chaudhuri, 2006).

In the context of banking service, personal experience of using banking services will produce emotional reactions (Marinkovic \& Obradovic, 2015). Such satisfactory and unsatisfactory reactions will result in a positive and negative experience. Take online banks in Finland as an example, it is found that there is a higher ratio of users switching to online banking after a having negative experience in transactions via physical banks (Karjaluoto, Mattila, \& Pento, 2002). Similar user reactions have also been verified in studies related to user experience after using information technology or e-banking services (Liébana-Cabanillas et al., 2016; Wang et al., 2017). Therefore, we believe that the emotional reaction of consumers after using online banking is worthy of follow-up discussion.

\subsection{Utilitarian and Hedonic Emotions}

Utilitarian in users refer to products that are equipped with the following effects: helpful, practical, useful, controllable, problem-solving, and productive (Baltas, Kokkinaki, \& Loukopoulou, 2017; Voss, Spangenberg, \& Grohmann, 2003). Utilitarian products should be safe, responsible, confident (Chen, Lee, \& Yap, 2016; Chitturi, Raghunathan, \& Mahajan, 2008) and could be accessed at any time or place through multiple service channels (Liao \& Cheung, 2002). Other studies on utilitarian in service suggest the following features: efficient, effective, helpful, functional, demand fulfilling, beneficial, useful, productive, controllable, and problem-solving (Baltas et al., 2017; Park \& Ha, 2016).

Hedonic in users refer to products equipped with the following effects: pleasant, nice, happy, agreeable, friendly, and actives (Arnold \& Reynolds, 2003; Baptista \& Oliveira, 2015). Users can have a fun and pleasant experience while using a product due to its beautiful color, graphic design, audio, and video signals established in the interface (Van der Heijden, 2004). Besides, hedonic can bring users the following feelings: fun, exhilarative, amusing, beautiful, pleasant, enjoyable, sophisticated, cheerful, and exciting (Steg, Perlaviciute, Van der Werff, \& Lurvink, 2014).

From the perspective of consumers' adoption behavior, hedonic outcomes were mainly for leisure that brings personal happiness and relaxation (Van der Heijden, 2004), while utilitarian outcomes were mostly for work which acts as a tool for creating productivity (Brown \& Venkatesh, 2005). In other words, utilitarian usually comes with an expected goal, and hedonic feeling is usually generated from a happy atmosphere without any expected goal (Wu \& Lu, 2013). For example, the function of social network systems is usually about sharing stories, photographs, and video clips for personal pleasure.

According to regulatory focus theory, consumers would like to achieve prevention goals and promotion goals via transactions (Higgins, 2001; Zhang, Craciun, \& Shin, 2010). Prevention goals refer to functions that the customers believe a product can bring and whether the customer's utilitarian motivations are achieved. Promotion goals refer to the emotions that the customers hope the product can give, and achieve their hedonic motivations (Khan, Dhar, \& Wertenbroch, 2005; Roy $\& \mathrm{Ng}, 2012$ ). Among them, utilitarian and hedonic both focus on the emotional responses of the consumption experience. While utilitarian is a prevention emotion for functionality and benefit with the provision of confidence and security, hedonic is the promotion emotion of inner value such as delight, excitement, and cheerfulness (Chitturi et al., 2008). Similar studies confirmed that achieving the prevention goals and promotion goals of a user will result in positive user experience, otherwise negative user experience will arise (Higgins, 2001). However, it is still not clear whether the emotional response of customers is based on their utilitarian or hedonic after they have received positive or 
negative consumption experiences (Chang \& Chen, 2015). In other words, it is not explicit whether users care more about the practical function of a product or the joy after using it.

\subsection{Post Adoption Behavior}

There are three main types of post-adoption behavior, including recommendation, complaint, and continuance intention (Chea \& Luo, 2008; Luo \& Chea, 2018). AET believes that the concepts of recommendation and complaint are derived from affective reactions (Fisher, 2002; Springett, 2009). A user may recommend others when his demand is achieved by the provided product, otherwise, complaints tend to be raised. On the other hand, expectation confirmation theory (ECT) points out that continuance intention is the follow-up reaction of consumers' comparison between their cognitive performance and expectations after using a specific product or service (Hossain \& Quaddus, 2012; Oliver, 1977). Therefore, according to these theories, cognitive assessment and affective experience can jointly determine specific behaviors.

In detail, the recommendation is a behavior that one telling others about products or services they like and wish all can use the products or services (Bougie, Pieters, \& Zeelenberg, 2003). In marketing, the recommendation mechanism is very powerful and influential. It can not only improve customer loyalty but also achieve higher effectiveness than advertising. The user's recommendation is mainly induced by the fulfillment of their requirements. When the performance of a product or service is superior to the user's expectation, one will recommend others as feeling satisfied.

Complain is a specific behavior, which means that the negative experience of a person is informed of another (Tronvoll, 2011). For example, when a customer uses a product, he tends to inform other people about their usage status and the product's shortcomings if the actual performance does not meet his expectation. The higher the customer's expectations are, the greater the level of complaint might be.

Continuance intention refers to the willingness to use a specific product or service continuously. Previous studies that discussed the main reasons that affect continuance intention were mostly focused on customer satisfaction. When the customer feels satisfied with a product or service, he or she will be willing to use it continuously (Bhattacherjee, 2001; Hong, Lin, \& Hsieh, 2017).

In the context of online banking services, users' continuous usage behavior is the most important part, and it is also a factor frequently discussed by scholars (Foroughi, Iranmanesh, \& Hyun, 2019; Sharma \& Sharma, 2019). To have a more comprehensive understanding of customers' subsequent usage behaviors, not only the rational level of users but also the emotional level should be included in the scope of relevant research. This can be, for example, whether the reaction caused by emotional factors will have a direct impact on user satisfaction and customer continuance intention.

\section{THE RESEARCH METHODOLOGY}

\subsection{Hypothesis Development}

This study proposes a research model based on prior developed hypotheses to investigate the relationship among user experience, utilitarian and hedonic emotions, satisfaction, continuance intention, and recommendation as shown in Figure 1.

According to AET, the emotional reactions of organization members from the perspective of event response includes expressions of positive and negative attitudes (Fisher, 2002). Different attitudes will lead to different behaviors (Ayo, Oni, Adewoye, \& Eweoya, 2016; Maslowska, Malthouse, \& Collinger, 2016).

Liao and Cheung (2002) studied the psychological feelings of users and proposed that the user experience of the service shall include the enjoyment, pressure, and nervousness; also, the feeling of receiving friendly, clear, and easy-to-follow instructions. In addition, different users could use different functions yet result in the same emotion (Springett, 2009). The interaction between user 
Figure 1. The research model

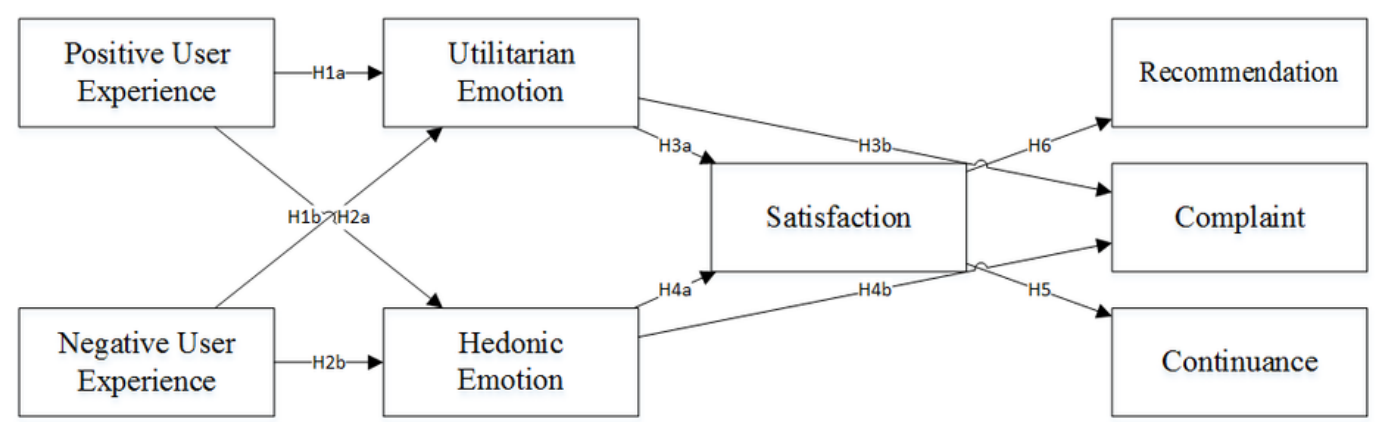

experience and brand could create the relationship between enterprise and consumers; further, the established mutual trust is a kind of emotional expression.

In terms of online banking service, the emotional state will result in users' feelings of pleasant or unpleasant, and such positive or negative feelings will affect their satisfaction (Al-Eisa \& Alhemoud, 2009; Mahal, 2016; Nam et al., 2019). Researchers pointed out that web interface design, the richness of text content, and multimedia in online banking all affect customers' trust and emotion (French, Liu, $\&$ Springett, 2007). Based on the aforementioned discussions, the following hypotheses are proposed.

H1a. The positive user experience of online banking services will have a positive impact on utilitarian emotion.

H1b. The positive user experience of online banking services will have a positive impact on hedonic emotion.

H2a. The negative user experience of online banking services will have a negative impact on utilitarian emotion.

$\mathrm{H} 2 \mathrm{~b}$. The negative user experience of online banking services will have a negative impact on hedonic emotion.

Based on AET, Chea and Luo (2009) summarized the ECT and customer use behavior for research with the focus on the emotional level and found that users would be more willing to recommend the online service when they showed positive emotions concerning such service, and such emotion would also affect the satisfaction. Other researchers also believed that emotional factors in the AET were temporary emotions induced by events which would not last long (Barnes, Ponder, \& Hopkins, 2015; Springett, 2009). Therefore, users may continue to use the service due to functional incentives. However, the continuance intention of such usage might result in negative emotions and dissatisfying user experience.

The factors affecting continuance intention of online services by users also include perception of online service quality, and such perception will affect the customer satisfaction and the continued use (Liébana-Cabanillas et al., 2016; Ozkan-Tektas \& Basgoze, 2017). Thus, we propose that:

H3a. The utilitarian emotion of online banking services will have a positive impact on satisfaction. H4a. The hedonic emotion of online banking services will have a positive impact on satisfaction.

Complaints by a user may be caused by negative emotions from failed services (Bougie et al., 2003). Furthermore, the cause of the negative emotional reaction can be the failure of meeting the expected service. A consumer with intense emotional reactions (such as anger) could easily create irrational behaviors, such as criticize, not to use, get angry, and complain (Gross \& John, 2003). 
So, complaint behaviors were very important for the online market to maintain customer royalty (Wu, 2013). Effective handling of complaints could lead to improvements in interactions between complainant and observer (Einwiller \& Steilen, 2015). The above discussions have led to a hypothesis:

H3b. The utilitarian emotion of online banking services will have a negative impact on the complaints. H4b. The hedonic emotion of online banking services will have a negative impact on the complaints.

Regarding the post-adoption behaviors, satisfaction is the reaction and attitude of using the product and is a kind of descriptive perception of attitude (Casaló, Flavián, \& Guinalíu, 2008; LiébanaCabanillas et al., 2016). Thus, satisfaction was an important antecedent affecting the three kinds of post-adoption behaviors (Chea \& Luo, 2008; Luo \& Chea, 2018; Wu, 2013). In the online services, the satisfaction should include the functional, interface design, and holistic aspects (Sikdar, Kumar, \& Makkad, 2015; Wu, 2013; Zhu \& Chen, 2010).

Consumers would be willing to continue to use a product or a service when the satisfaction was met ( $\mathrm{Lu}$, Wang, \& Lu, 2019), the intention of continuance and "another purchase" by the consumer was the same (Bhattacherjee, 2001). Customer loyalty is referred to the commitment of another purpose, such as the intention of continuance (Brunner, Stöcklin, \& Opwis, 2008). Thus, the primary factor affecting the continuance intention of using service might satisfaction (Chea \& Luo, 2009).

Recommendation behavior is about recommending favored merchandise or service to others (Bougie et al., 2003; Kowatsch \& Maass, 2010); satisfaction is one of the primary reasons for users to recommendation the merchandise or service to others (Altunel \& Erkurt, 2015; Casaló et al., 2008) and can meet customers' satisfaction (Reichheld, 2003). They revealed that the factors of the user's willingness of recommendation included gaining benefits, being helpful to others, willing to share, and seeking self-expression. Hence, we hypothesize that:

H5. The satisfaction of online banking services will have a positive impact on the continuance intention. H6. The satisfaction of online banking service users will have a significant impact on the recommendation for others to use.

\subsection{Research Procedures and Participants}

The target audience is directly aimed at users who already use online banking services because the theme of the study is the user's experience using online banking services. Therefore, qualified respondents must have experience in using online banking services. The research questionnaire was created, distributed, and managed through the Google Forms platform. Subsequently, a convenient sampling method was used to publish the questionnaire URL and send email invitations on relevant social media. Respondents who completed the questionnaire will receive a gift certificate as feedback. A total of 308 questionnaires were received; and a total of 288 valid ones were retained after deleting invalid samples with missing data. Male samples were 57.6\%, while females were $42.4 \%$. Students accounted for $55.6 \%$, and those with college and graduate school education accounted for $98.5 \%$. The samples with the age of 21 to 30 were $86.8 \%$.

\subsection{Measurement Envelopment}

The survey method was used based on the questions of the Likert scale, where 1 to 5 (1 represents strongly disagree, 5 represents strongly agree) indicating five different degrees. The process of questionnaire design includes three steps: (1) Review prior studies to find out correlation among variables and establish models and hypotheses. (2) Design the preliminary questionnaire based on the evaluation variables from the literature. (3) Carry out the pilot test on the questionnaire. (4) Integrate the outcomes of the pilot test into the final questionnaire. (5) Distributed the questionnaires via the online platforms. Survey items of the variables in this model are shown in Table 1. 
Journal of Global Information Management

Volume 29 •Issue 6 • November-December 2021

\section{Table 1. Measurement items of variables}

\begin{tabular}{|c|c|c|}
\hline Variables & Survey items & Sources \\
\hline \multirow[t]{8}{*}{ Positive user experience } & The use of online banking services in the past could lead to cost-saving. & Nami (2009) \\
\hline & $\begin{array}{l}\text { The transaction could be quickly completed during the use of online banking services } \\
\text { in the past. }\end{array}$ & Nami (2009) \\
\hline & The online banking service could be accessed (used) at any time. & Nami (2009) \\
\hline & The online banking service was equipped with the function I need. & Nami (2009) \\
\hline & The use of online banking services did not make me feel nervous. & Liao \& Cheung (2002) \\
\hline & The use of online banking services was easy for me. & Liao \& Cheung (2002) \\
\hline & I could surely control every transaction during the use of online banking services. & Liao \& Cheung (2002) \\
\hline & I believed the transaction was secured during the use of online banking services. & Liao \& Cheung (2002) \\
\hline \multirow[t]{6}{*}{ Negative user experience } & The long wait during the use of online banking services. & Chea \& Luo (2009) \\
\hline & Unexpected interruption during the use of online banking services. & Chea \& Luo (2009) \\
\hline & Transaction failure during the use of online banking services. & Chea \& Luo (2009) \\
\hline & $\begin{array}{l}\text { I was forced to do shopping via webpage advertisements during the use of online } \\
\text { banking services. }\end{array}$ & Zhu \& Chen (2010) \\
\hline & $\begin{array}{l}\text { It took complicated authentication steps to log in during the use of online banking } \\
\text { services. }\end{array}$ & Zhu \& Chen (2010) \\
\hline & $\begin{array}{l}\text { Insufficient information provided during the use of online banking services (for } \\
\text { example changes in currency rates of various countries). }\end{array}$ & Zhu \& Chen (2010) \\
\hline \multirow[t]{5}{*}{ Utilitarian } & I expect online banking services are secure. & Chitturi \& Raghunathan (2008) \\
\hline & I expect online banking service is easy to use. & Dabholkar (1996) \\
\hline & I expect online banking service is fast. & Dabholkar (1996) \\
\hline & I expect online banking service is trustworthy. & Dabholkar (1996) \\
\hline & I expect online banking services are convenient. & Liao \& Cheung (2002) \\
\hline \multirow[t]{4}{*}{ Hedonic } & The use of online banking services can make me feel pleasant. & Okada (2005) \\
\hline & I can enjoy the use of online banking services. & Dabholkar (1996) \\
\hline & The use of online banking services can make me trendy. & $\begin{array}{l}\text { Chitturi \& Raghunathan \& } \\
\text { Mahajan (2008) }\end{array}$ \\
\hline & The use of online banking services can make my life better technologically. & $\begin{array}{l}\text { Chitturi \& Raghunathan \& } \\
\text { Mahajan (2008) }\end{array}$ \\
\hline \multirow[t]{4}{*}{ Satisfaction } & I am satisfied with the functions provided by online banking services. & $\begin{array}{l}\text { Casalo, Flavian and Guinaliu } \\
(2008)\end{array}$ \\
\hline & I am satisfied with the website design of online banking services. & $\begin{array}{l}\text { Casalo, Flavian and Guinaliu } \\
(2008)\end{array}$ \\
\hline & I am satisfied with the overall online banking service. & $\begin{array}{l}\text { Casalo, Flavian and Guinaliu } \\
(2008)\end{array}$ \\
\hline & I feel good about online banking services. & Oliver (1997) \\
\hline \multirow[t]{4}{*}{ Complaint } & To me online banking service is bad. & Higgins (1997) \\
\hline & I will tell others not to use online banking services. & Higgins (1997) \\
\hline & The use of online banking services will make me angry. & Higgins (1997) \\
\hline & I complain a lot during the use of online banking services. & Higgins (1997) \\
\hline \multirow[t]{3}{*}{ Continuance } & I will continue to use online banking services. & Oliver (1997) \\
\hline & Online banking services will continue to accompany my life. & Chea \& Luo (2009) \\
\hline & I will not give up using online banking services. & Chea \& Luo (2009) \\
\hline \multirow[t]{3}{*}{ Recommendation } & I will actively recommend others to use online banking services. & Chea \& Luo (2009) \\
\hline & When another person asked me about online banking service, I will recommend it. & Chea \& Luo (2009) \\
\hline & Online banking service is worthy of my recommendation to others. & Chea \& Luo (2009) \\
\hline
\end{tabular}


The descriptive analysis and reliability and validity tests were carried out with the aid of SPSS software in this study. The Smart-PLS was then used for analyzing the overall fitness of the model to determine the adaptability among various aspects.

\section{DATA ANALYSIS}

\subsection{Demographics, and Reliability and Validity Tests}

In the reliability analysis, except for the negative user experience of 0.688 , all other Cronbach's Alpha values were greater than 0.7 (see Table 2). The test of validity was conducted by Exploratory Factor Analysis (EFA), where those questions with factor load lower than 0.5 were eliminated and all constructs were adjusted to a single factor to ensure the validity of the questionnaire (see Table 3). The analysis of the Pearson correlation coefficient was applied for evaluating the linear relationship between two variables (see Table 4). Except for the insignificant relationship between negative user experience and expectation emotion, all other values were significant with the level of significance above 0.01 , indicating good correlation among all constructs.

\subsection{Hypothesis Testing}

The SmartPLS was used for analyzing the direct effects among the variables based on the standardized path coefficient values. The Bootstrapping method was also used for analyzing $t$ values on the paths in the overall model. The judgment of result significance was based on the evaluation standard of the two-tailed t-test (for $\mathrm{t}>1.96$ then $\mathrm{p}$-values $<0.05$; for $\mathrm{t}>2.576$ then $\mathrm{p}$-value $<0.01$ ). The $\mathrm{R} 2$ value was utilized to determine the interpretation ability of the model. The results of hypothesis testing are shown in Table 5.

The results show that the $t$ value of the impact of positive user experience on utilitarian is 7.096, the coefficient value is 0.463 , and the p-value reaches the level of significance. Thus, H1a is supported by the results. The t value of the impact of positive user experience on hedonic is 5.546, the coefficient value is 7.01, and the p-value demonstrates the level of significance. Thus, H1b is supported.

The $t$ value of the impact of negative user experience on utilitarian is 1.118 , the p-value is 0.92 ( $p>0.05$ ), and the coefficient value is -0.071 . Thus, $H 2$ a does not hold. The $t$ value of the impact of negative user experience on hedonic is 0.918 , the p-value is $0.64(\mathrm{p}>0.05)$, and the coefficient value is 0.064 . Thus, $\mathrm{H} 2 \mathrm{~b}$ does not hold. The $\mathrm{t}$ value of the impact of utilitarian on satisfaction is 1.305 , the $\mathrm{p}$-value is 0.212 , and the coefficient value is 0.093 . Thus, H3a does not hold.

The $t$ value of the impact of hedonic on satisfaction is 3.56 , the coefficient value is -0.287 , and the $\mathrm{p}$-value reaches the level of significance. Thus, $\mathrm{H} 3 \mathrm{~b}$ is also supported. The t value of the impact of utilitarian on the complaint is 6.16 , the coefficient value is 6.16 , and the p-value reaches the level of significance.

Thus, H4a holds true. The t value of the impact of hedonic on the complaint is 1.901 , the p-value is 0.003 (less than 0.01 ), and the coefficient value is -0.151 . Thus, $\mathrm{H} 4 \mathrm{~b}$ does not hold true. The $\mathrm{t}$ value of the impact of satisfaction on continuance intention is 13.622 , the coefficient value is 0.582 , and the p-value reaches the level of significance. Thus, H5 holds true. The t value of the impact of satisfaction on recommendation is 11.637 , the coefficient value is 0.583 , and the p-value reaches the level of significance. Thus, H6 is supported (as shown in Table 5).

The R2 values of continuance intention and recommendation are higher than others, which are 0.338 and 0.339 respectively (as shown in Table 5). The complaint has the lowest value, which is 0.148 . The R2 of utilitarian is 0.240 while the hedonic is 0.177 and the satisfaction is 0.220 .

\subsection{Results Discussions}

According to the results, this study found that positive user experience of online banking service has a positive significant impact on utilitarian emotion (hypothesis $\mathrm{H} 1 \mathrm{a}$ ). This finding indicates that after 
Table 2. Reliability test

\begin{tabular}{|l|c|c|}
\hline Variables & Measurement Item Number & Cronbach's alpha \\
\hline Positive user experience & 8 & 0.749 \\
\hline Negative user experience & 6 & 0.688 \\
\hline Utilitarian & 5 & 0.804 \\
\hline Hedonic & 4 & 0.780 \\
\hline Satisfaction & 4 & 0.843 \\
\hline Complaint & 4 & 0.863 \\
\hline Continuance & 3 & 0.911 \\
\hline Recommendation & 3 & 0.891 \\
\hline
\end{tabular}

Table 3. KMO sampling adequacy and Bartlett sphericity test

\begin{tabular}{|l|c|c|c|c|}
\hline \multirow{2}{*}{ Variables } & \multirow{2}{*}{ KMO } & \multicolumn{2}{|c|}{ Bartlett Sphericity test } \\
\cline { 2 - 5 } & & Chi-square test & df & Significance \\
\hline Positive user experience & 0.739 & 218.661 & 6 & 0.000 \\
\hline Negative user experience & 0.569 & 150.033 & 6 & 0.000 \\
\hline Utilitarian & 0.576 & 666.781 & 6 & 0.000 \\
\hline Hedonic & 0.694 & 210.557 & 3 & 0.000 \\
\hline Satisfaction & 0.719 & 312.028 & 3 & 0.000 \\
\hline Complaint & 0.684 & 479.085 & 3 & 0.000 \\
\hline Continuance & 0.733 & 620.609 & 3 & 0.000 \\
\hline Recommendation & 0.744 & 515.076 & 3 & 0.000 \\
\hline
\end{tabular}

\section{Table 4. Correlation Analysis}

\begin{tabular}{|c|c|c|c|c|c|c|c|c|}
\hline & PE & NE & Uti & Hed & Sat & Com & CI & Rec \\
\hline PE & 1.000 & & & & & & & \\
\hline NE & $-0.248^{* *}$ & 1.000 & & & & & & \\
\hline Uti & $0.427 * *$ & -0.101 & 1.000 & & & & & \\
\hline Hed & $0.400 * *$ & $-0.124 *$ & $0.432 * *$ & 1.000 & & & & \\
\hline Sat & $0.633^{* *}$ & $-0.298 * *$ & $0.252 * *$ & $0.446 * *$ & 1.000 & & & \\
\hline Com & $-0.496^{* *}$ & $0.526^{* *}$ & $-0.298 * *$ & $-0.279 * *$ & $-0.490^{* *}$ & 1.000 & & \\
\hline $\mathrm{CI}$ & $0.643^{* *}$ & $-0.248 * *$ & $0.462 * *$ & $0.467 * *$ & $0.568 * *$ & $-0.564 * *$ & 1.000 & \\
\hline $\operatorname{Rec}$ & $0.573 * *$ & $-0.161 * *$ & $0.322 * *$ & $0.454 * *$ & $0.559 * *$ & $-0.393 * *$ & $0.650 * *$ & 1.000 \\
\hline
\end{tabular}

PE: Positive User Experience, NE: Negative User Experience, Uti: Utilitarian Emotion, Hed: Hedonic Emotion, Sat: Satisfaction, Com: Complaint, Con: Continuance, Rec: Recommendation for Others $* * \mathrm{p}<0.01, * \mathrm{p}<0.05$ 
Table 5. Results of hypothesis testing

\begin{tabular}{|c|c|c|c|c|c|c|}
\hline Hypothesis & Path & Coefficient value & t value & p-value & $\mathbf{R}^{2}$ (Variable) & Result \\
\hline H1a & PE®Uti & 0.463 & 7.096 & $* *$ & 0.240 (Uti) & Accept \\
\hline H1b & PE®Hed & 0.396 & 5.546 & $* *$ & $0.177(\mathrm{Hed})$ & Accept \\
\hline H2a & NE®Uti (-) & -0.071 & 1.118 & & & Reject \\
\hline H2b & NE®Hed (-) & 0.064 & 0.918 & & & Reject \\
\hline H3a & Uti@Sat & 0.093 & 1.305 & & 0.220 (Sat) & Reject \\
\hline H3b & Uti®Com (-) & -0.287 & 3.56 & $* *$ & $0.148(\mathrm{Com})$ & Accept \\
\hline H4a & Hed®Sat & 0.415 & 6.16 & $* *$ & & Accept \\
\hline H4b & Hed®Com (-) & -0.151 & 1.901 & & & Reject \\
\hline H5 & Sat ${ }^{\circledR}$ Con & 0.582 & 13.622 & $* *$ & 0.338 (Con) & Accept \\
\hline H6 & Sat ${ } \operatorname{Rec}$ & 0.583 & 11.637 & $* *$ & $0.339(\operatorname{Rec})$ & Accept \\
\hline \multicolumn{7}{|c|}{$\begin{array}{l}\text { PE: Positive User Experience, NE: Negative User Experience, Uti: Utilitarian Emotion, Hed: Hedonic Emotion, Sat: } \\
\text { Satisfaction, Com: Complaint, Con: Continuance, Rec: Recommendation for Others } \\
*^{*} \mathrm{p}<0.01,{ }^{*} \mathrm{p}<0.05\end{array}$} \\
\hline
\end{tabular}

having a positive user experience, users will gain functional and practical benefits, thus leading to confidence and security feelings. This finding is consistent with results from Chitturi et al. (2008).

The hypothesis H1b in this study is for verifying whether the positive user experience has a significant positive impact on hedonic emotion, and it has been supported by the result, which indicates that the better design of the display interface of online banking can improve the hedonic sense of users. Also, the positive user experience of online banking will lead to the emotion of enjoying happiness and excitement (Chitturi et al., 2008).

About the positive user experience survey questions, the cost-saving relative question has been deleted due to the low factor loading. Nami (2009) pointed out that online banking could result in cost saving. However, there are many Automatic Teller Machines (ATM) across the region in Taiwan. Thus, it is very convenient for users to interact with the banks, which can reduce the intention of using online banking services for cost-saving. This could explain why this question has been deleted.

The analysis results indicate that neither hypothesis $\mathrm{H} 2 \mathrm{a}$ nor hypothesis $\mathrm{H} 2 \mathrm{~b}$ holds. Certain samples were selected for exploratory interview in this study, and the results showed that respondents did not encounter the negative experiences in the questionnaire, such as long wait during online service, service failure, or sudden service interruption (Rose, Meuter, \& Curran, 2005; Ryan \& Valverde, 2006). It could be the reason that network infrastructures have been generally improved. Therefore, users never encountered the service failure situations listed in the questionnaire, thus leading to an insignificant result.

Previous studies pointed out that utilitarian had a positive significant impact on satisfaction (Chitturi et al., 2008). Yet, it was shown in this study that hypothesis H3a was not be supported. Perhaps, in the initial stage of online banking development, there was a lack of system functions provision from online banking service providers. In terms of hypothesis $\mathrm{H} 3 \mathrm{~b}$, when users are not satisfied with the system from the utilitarian perspective, they will complain about the system. The results indicate that which is consistent with the theory proposed by Bougie et al. (2003) regarding negative emotions generated from user-facing failed service.

The results of this study show that hedonic has a positive significant impact on satisfaction $(\mathrm{H} 4 \mathrm{a})$. This is consistent with the idea that user satisfaction will be enhanced when the prevention goal and promotion goal were achieved (Chitturi et al., 2008). Yet, the hedonic promotion goal will have a not positive and significant impact on complaints according to hypothesis H4b. 
When comparing the effects from the antecedents of satisfaction, the results show that the impact of hedonic on satisfaction is greater than utilitarian (H3a was rejected while $\mathrm{H} 4 \mathrm{a}$ was accepted). Thus, by providing more system functions, users could be satisfied. However, after all, functions were popularized on the market, it became more difficult to ensure the user's satisfaction with the system. If this system can create hedonic emotion, it will be differentiated by users from other competitors.

When comparing the effects from the antecedents of the complaint, the results show that the utilitarian has a greater impact on complaint than hedonic ( $\mathrm{H} 3 \mathrm{~b}$ was accepted while $\mathrm{H} 4 \mathrm{~b}$ was rejected). It indicated in the result that, from the perspective of user benefit, the use of online banking leads to more functional benefits rather than enjoyment benefits. On this basis, if online banking fails to provide the service to meet the user's hedonic needs, the user may still be willing to use the service again without complaint. However, once any malfunction causes service failure, users would feel a loss of their benefits, which led to complaints. This is consistent with the explanations provided by Chitturi et al. (2008).

In terms of hypothesis H5, the satisfaction of a user of online banking service has a positive and significant impact on continuance intention, and it is supported by the result. It is also consistent with the suggestions of Bhattacherjee (2001) and Chea and Luo (2009) that users will be willing to continue using this service when satisfaction has been met. Hypothesis H6 also supported, in which the satisfaction of a user of online banking service has a positive significant impact on the recommendation to others. This is also consistent with the prior studies that satisfaction was one of the primary reasons for recommending other users to use the service (Casaló et al., 2008).

\section{CONCLUSION}

This study tended to explore how utilitarian and hedonic emotion impact on post-adoption behaviors in the online banking environment. The result shows that the positive user experience has a positive and significant impact on the generation of utilitarian emotion. We also found that online banking users treat the positive user experience this time as the expectation of the next use, which means users would compare the experience of the current use with past experiences. Moreover, in the sense of utilitarian emotion, users care about successfully achieving the goal of the operation, such as completing a wire transfer transaction in the online banking environment. Therefore, the design of online functions must be based on the principle of allowing users to successfully fulfill their purposes of using online banking.

In terms of hedonic emotion, this study found that positive user experience has a positive and significant impact on the generation of hedonic emotion. As suggested by Chitturi et al. (2008) and Higgins (2001), the hedonic benefit was about enjoying the emotions of happiness and excitement. Thus, the positive user experience of online banking can bring emotional happiness for creating a kind of spiritual benefit (Wu \& Lu, 2013).

We have also proven the significant positive relationship between hedonic emotion and satisfaction. When users have pleasant and nice feelings while using the system, the satisfaction will be enhanced, and this is in line with the suggestions of the literature (Chitturi et al., 2008; Turel, 2015). If users have fun while completing their working tasks in the online banking, a sense of beauty and extra enjoyment could stimulate users' satisfaction (Okada, 2005; Van der Heijden, 2004; Voss et al., 2003). Hedonic emotion comes with certain leisure effects and the value of causing personal pleasant feelings and relaxation. Therefore, providers of online banking services must consider enhancing such hedonic effects in the system to enhance user satisfaction.

Utilitarian emotion has a positive and significant impact on satisfaction. When users' demand has been met by system function, user satisfaction will be enhanced (Chitturi et al., 2008). It complies with the suggestions of literature that the design of the system function of online banking service must include ease of use, operational interaction, navigation, security, and download speed (Elradi, Abdullah, Jusoh, \& Jabar, 2017). Besides, attention must be paid to the user's ability to fast confirm 
their transactions, and how convenient this function is (Liao \& Cheung, 2002), both of which will have a direct impact on the user's satisfaction. Above mentioned suggestions must be taken into consideration when providing online banking service.

Regarding the post-adoption behaviors, the current study has proven the positive significant impact of satisfaction on continuance intention, which is in line with the previous studies (Bhattacherjee, 2001; Chea \& Luo, 2009) that users are willing to continue using the service when user satisfaction is met. Particularly, the result reveals that the major impact factor of the complaint is the dissatisfaction of system functionality (utilitarian emotion). For users, online banking is a tool to achieve their goals, and if their service requirement is not fulfilled, a complaint may arise. To reduce complaints, the stability of the system must be maintained. Moreover, system maintenance and software updates must be performed, and the bank must be ensured that virus attacks do not affect the transaction and system environment to provide a secure and fast transaction environment. Doing these practices help complete system recovery in the shortest amount of time in the event of unexpected system damage, and it can reduce complaints and further increase user satisfaction.

As for the post-adoption recommendation, it is found that satisfaction has a positive significant impact on recommendation, which is in line with the findings suggested by Bougie et al. (2003) and Casaló et al. (2008), that satisfaction is one of the primary reasons for users' recommendation of the service to others.

\section{IMPLICATIONS AND LIMITATIONS}

\subsection{Theoretical Contributions}

This study provides several theoretical contributions to online service research. First, it expands the application of AET to explain the degree of positive or negative experiences of online banking users that affects post-adoption behaviors. Specifically, AET is mainly used to discuss the job performance of employees in an enterprise environment (Fisher, 2002). We firstly extend the theory to discuss the post-adoption behavior of users in an online banking service context. This deepens our understanding of the behavior of users of online banking services.

Secondly, we further adopted utilitarian emotion and hedonics emotion as the operational constructs of the emotional reactions in the original AET model, which is also an innovation in related research. Finally, Consumers' post-adopt behavior is an important influencing factor of customer retention theory (Chea \& Luo, 2008). This study gives the retention theory more explanatory power in the online banking service context.

\subsection{Practical Implications}

The current study shows that, even with daily transactions as the main task, banks must pay attention to the hedonic effect, which may be brought about by the user's positive experience and affect postadoption behavior, such as continuance intention and recommendation. For banks, if the strategic goal is to pursue a large transaction volume, they should keep upgrading the online systems continuously and comprehensively. Furthermore, if it is too difficult to create a pleasant atmosphere, at least banks should be invested more in creating a relaxed online environment for customers.

The design of online systems should be based on utilitarian and hedonic benefits. It is recommended to divide the objectives of the online banking system as the utilitarian of functional requirements and the hedonic of leisure needs (Brown \& Venkatesh, 2005; Van der Heijden, 2004; Wu \& Lu, 2013), and incorporating weight calculation into system design. Most users treat online banking services as a tool rather than just a technology. Thus, aiming for customers' functional satisfaction is key for the bank. However, continuous user satisfaction is difficult to achieve by simply enhancing system functionality. Competitors can also easily imitate this, thereby reducing the competitive advantage. Therefore, it is important to the bank to focus on the design at the hedonic level which can invisibly 
evoke the user's feelings. The hedonic level design can create a feeling which is more unique and difficult for imitation.

Banks should consider how to use satisfied users to make recommendations as a marketing and promotion strategy. Therefore, the first task of adopting online banking is to achieve user satisfaction before recommendation. The functions of online banking services should be designed according to the needs of various kinds of users. These features include bill payment, loan application, service channel, service security, content richness, data correctness, system compatibility, and so on (Adapa \& Roy, 2017; Liao \& Cheung, 2002).

\subsection{Limitations and Future Research}

There are three limitations to this study. First, the questionnaire is distributed through an online social network. Most people in Taiwan today know how to use the Internet, but there are still a few people who do not know how to use the Internet to fill out the questionnaire. Second, the survey samples are mainly from two of the largest cities in Taiwan. Third, due to personal habits, users surveyed may only focus on certain types of services when filling out the survey, which in turn may affect the results of the current study.

In the future, the negative user experience of the online service should be investigated further. It is recommended that failure service cases in online banking can be a research topic for enriching the current model. Second, the two hypotheses about the negative user experience of utilitarianism and hedonism are not statistically significant. It is suggested that this clue can be further studied. Fourth, research on hedonic and utilitarian motivations can be replicated on the topics of online services of smartphones and adoption in other industries, to create a broader and deeper discussion.

\section{ACKNOWLEDGMENT}

This research was supported by the Ministry of Science and Technology in Taiwan, grant number 107-2410-H-004-091-MY2, MOST 109-2410-H-035-046. 


\section{REFERENCES}

Adapa, S., \& Roy, S. K. (2017). Consumers' post-adoption behaviour towards Internet banking: Empirical evidence from Australia. Behaviour \& Information Technology, 36(9), 970-983. doi:10.1080/0144929X.2017.1319498

Ahmad, A., \& Al-Zu'bi, H. A. (2011). E-banking functionality and outcomes of customer satisfaction: an empirical investigation. International Journal of Marketing Studies, 3(1), 50-65.

Aker, J. C., \& Mbiti, I. M. (2010). Mobile phones and economic development in Africa. The Journal of Economic Perspectives, 24(3), 207-232. doi:10.1257/jep.24.3.207

al Afeef, M., Singh, D., \& Ahmad, K. (2012). The Inñuence of Demographic Factors and User Interface on Mobile Banking Adoption: A Review. Journal of Applied Sciences, 12(20), 2082-2095. doi:10.3923/jas.2012.2082.2095

Al-Eisa, A. S., \& Alhemoud, A. M. (2009). Using a multiple-attribute approach for measuring customer satisfaction with retail banking services in Kuwait. International Journal of Bank Marketing, 27(4), $294-314$. doi:10.1108/02652320910968368

Altunel, M. C., \& Erkurt, B. (2015). Cultural tourism in Istanbul: The mediation effect of tourist experience and satisfaction on the relationship between involvement and recommendation intention. Journal of Destination Marketing \& Management, 4(4), 213-221. doi:10.1016/j.jdmm.2015.06.003

Anouze, A. L. M., \& Alamro, A. S. (2019). Factors affecting intention to use e-banking in Jordan. International Journal of Bank Marketing, 31(1), 86-112. doi:10.1108/IJBM-10-2018-0271

Arnold, M. J., \& Reynolds, K. E. (2003). Hedonic shopping motivations. Journal of Retailing, 79(2), 77-95. doi:10.1016/S0022-4359(03)00007-1

Asongu, S., \& Nwachukwu, J. C. (2018). Comparative human development thresholds for absolute and relative pro-poor mobile banking in developing countries. Information Technology \& People, 31(1), 63-83. doi:10.1108/ ITP-12-2015-0295

Ayo, C. K., Oni, A. A., Adewoye, O. J., \& Eweoya, I. O. (2016). E-banking users' behaviour: E-service quality, attitude, and customer satisfaction. International Journal of Bank Marketing, 34(3), 347-367. doi:10.1108/ IJBM-12-2014-0175

Bagozzi, R. P., Gopinath, M., \& Nyer, P. U. (1999). The role of emotions in marketing. Journal of the Academy of Marketing Science, 27(2), 184-206. doi:10.1177/0092070399272005

Baltas, G., Kokkinaki, F., \& Loukopoulou, A. (2017). Does variety seeking vary between hedonic and utilitarian products? The role of attribute type. Journal of Consumer Behaviour, 16(6), e1-e12. doi:10.1002/cb.1649

Baptista, G., \& Oliveira, T. (2015). Understanding mobile banking: The unified theory of acceptance and use of technology combined with cultural moderators. Computers in Human Behavior, 50, 418-430. doi:10.1016/j. chb.2015.04.024

Barnes, D. C., Ponder, N., \& Hopkins, C. D. (2015). The impact of perceived customer delight on the frontline employee. Journal of Business Research, 68(2), 433-441. doi:10.1016/j.jbusres.2014.06.005

Bhattacherjee, A. (2001). An empirical analysis of the antecedents of electronic commerce service continuance. Decision Support Systems, 32(2), 201-214. doi:10.1016/S0167-9236(01)00111-7

Bougie, R., Pieters, R., \& Zeelenberg, M. (2003). Angry customers don't come back, they get back: The experience and behavioral implications of anger and dissatisfaction in services. Journal of the Academy of Marketing Science, 31(4), 377-393. doi:10.1177/0092070303254412

Bradley, L., \& Stewart, K. (2003). The diffusion of online banking. Journal of Marketing Management, 19(910), 1087-1109. doi:10.1080/0267257X.2003.9728252

Brown, S. A., \& Venkatesh, V. (2005). Model of adoption of technology in households: A baseline model test and extension incorporating household life cycle. Management Information Systems Quarterly, 29(3), 399. doi: $10.2307 / 25148690$

Brunner, T. A., Stöcklin, M., \& Opwis, K. (2008). Satisfaction, image and loyalty: New versus experienced customers. European Journal of Marketing, 42(9/10), 1095-1105. doi:10.1108/03090560810891163 
Casaló, L. V., Flavián, C., \& Guinalíu, M. (2008). The role of satisfaction and website usability in developing customer loyalty and positive word-of-mouth in the e-banking services. International Journal of Bank Marketing, 26(6), 399-417. doi:10.1108/02652320810902433

Castañeda, J. A., Muñoz-Leiva, F., \& Luque, T. (2007). Web Acceptance Model (WAM): Moderating effects of user experience. Information \& Management, 44(4), 384-396. doi:10.1016/j.im.2007.02.003

Chang, C.-C., \& Chen, C.-W. (2015). Examining hedonic and utilitarian bidding motivations in online auctions: Impacts of time pressure and competition. International Journal of Electronic Commerce, 19(2), 39-65.

Chaudhuri, A. (2006). Emotion and reason in consumer behavior. Routledge. doi:10.4324/9780080461762

Chea, S., \& Luo, M. M. (2008). Post-adoption behaviors of e-service customers: The interplay of cognition and emotion. International Journal of Electronic Commerce, 12(3), 29-56. doi:10.2753/JEC1086-4415120303

Chea, S., \& Luo, M. M. (2009). eService Customer Retention: An Affective Events Theory Perspective. AMCIS 2009 Proceedings, 484.

Chen, C. Y., Lee, L., \& Yap, A. J. (2016). Control deprivation motivates acquisition of utilitarian products. The Journal of Consumer Research, 43(6), 1031-1047. doi:10.1093/jcr/ucw068

Chitturi, R., Raghunathan, R., \& Mahajan, V. (2008). Delight by design: The role of hedonic versus utilitarian benefits. Journal of Marketing, 72(3), 48-63. doi:10.1509/JMKG.72.3.048

Durucu, M., Isik, M., \& Calisir, F. (2019). What is more important to internet banking website users: Usability or functionality? International Journal of Business Information Systems, 30(2), 232-251. doi:10.1504/ IJBIS.2019.097536

Einwiller, S. A., \& Steilen, S. (2015). Handling complaints on social network sites-An analysis of complaints and complaint responses on Facebook and Twitter pages of large US companies. Public Relations Review, 41(2), 195-204. doi:10.1016/j.pubrev.2014.11.012

Elradi, M., Abdullah, R., Jusoh, Y. Y., \& Jabar, M. A. (2017). Internet Banking Service Quality in Malaysia: An Empirical Investigation. Journal of Telecommunication Electronic and Computer Engineering, 9(3-4), $151-156$.

Faroughian, F. F., Kalafatis, S. P., Ledden, L., Samouel, P., \& Tsogas, M. H. (2012). Value and risk in businessto-business e-banking. Industrial Marketing Management, 41(1), 68-81. doi:10.1016/j.indmarman.2011.11.012

Fisher, C. D. (2002). Antecedents and consequences of real-time affective reactions at work. Motivation and Emotion, 26(1), 3-30. doi:10.1023/A:1015190007468

Foroughi, B., Iranmanesh, M., \& Hyun, S. S. (2019). Understanding the determinants of mobile banking continuance usage intention. Journal of Enterprise Information Management, 32(6), 1015-1033. doi:10.1108/ JEIM-10-2018-0237

French, T., Liu, K., \& Springett, M. (2007). A card-sorting probe of e-banking trust perceptions. Proceedings of the 21st British HCI Group Annual Conference on People and Computers: HCI... but not as we know it, 1. doi:10.14236/ewic/HCI2007.5

Gross, J. J., \& John, O. P. (2003). Individual differences in two emotion regulation processes: Implications for affect, relationships, and well-being. Journal of Personality and Social Psychology, 85(2), 348-362. doi:10.1037/0022-3514.85.2.348 PMID:12916575

Higgins, E. T. (1997). Beyond pleasure and pain. The American Psychologist, 52(12), 1280-1300. doi:10.1037/0003-066X.52.12.1280 PMID:9414606

Higgins, E. T. (2001). Promotion and prevention experiences: Relating emotions to nonemotional motivational states. Academic Press.

Ho, C.-T. B., \& Lin, W.-C. (2010). Measuring the service quality of internet banking: Scale development and validation. European Business Review, 22(1), 5-24. doi:10.1108/09555341011008981

Hoehle, H., Scornavacca, E., \& Huff, S. (2012). Three decades of research on consumer adoption and utilization of electronic banking channels: A literature analysis. Decision Support Systems, 54(1), 122-132. doi:10.1016/j. dss.2012.04.010 
Holbrook, M. B., Lehmann, D. R., \& O'Shaughnessy, J. (1986). Using versus choosing: The relationship of the consumption experience to reasons for purchasing. European Journal of Marketing, 20(8), 49-62. doi:10.1108/ EUM0000000004662

Hong, J.-C., Lin, P.-H., \& Hsieh, P.-C. (2017). The effect of consumer innovativeness on perceived value and continuance intention to use smartwatch. Computers in Human Behavior, 67, 264-272. doi:10.1016/j. chb.2016.11.001

Hornbæk, K., \& Hertzum, M. (2017). Technology acceptance and user experience: A review of the experiential component in HCI. ACM Transactions on Computer-Human Interaction, 24(5), 33. doi:10.1145/3127358

Hossain, M. A., \& Quaddus, M. (2012). Expectation-confirmation theory in information system research: A review and analysis. In Information systems theory (pp. 441-469). Springer. doi:10.1007/978-1-4419-6108-2_21

Khan, U., Dhar, R., \& Wertenbroch, K. (2005). A behavioral decision theory perspective on hedonic and utilitarian choice. In S. Ratneshwar \& D. G. Mick (Eds.), Inside consumption: Frontiers of research on consumer motives, goals, and desires. Routledge.

Kim, J., \& Moon, J. Y. (1998). Designing towards emotional usability in customer interfaces-Trustworthiness of cyber-banking system interfaces. Interacting with Computers, 10(1), 1-29. doi:10.1016/S0953-5438(97)00037-4

Kowatsch, T., \& Maass, W. (2010). In-store consumer behavior: How mobile recommendation agents influence usage intentions, product purchases, and store preferences. Computers in Human Behavior, 26(4), 697-704. doi:10.1016/j.chb.2010.01.006

Ladhari, R., Souiden, N., \& Dufour, B. (2017). The role of emotions in utilitarian service settings: The effects of emotional satisfaction on product perception and behavioral intentions. Journal of Retailing and Consumer Services, 34, 10-18. doi:10.1016/j.jretconser.2016.09.005

Laukkanen, T. (2016). Consumer adoption versus rejection decisions in seemingly similar service innovations: The case of the Internet and mobile banking. Journal of Business Research, 69(7), 2432-2439. doi:10.1016/j. jbusres.2016.01.013

Legris, P., Ingham, J., \& Collerette, P. (2003). Why do people use information technology? A critical review of the technology acceptance model. Information \& Management, 40(3), 191-204. doi:10.1016/S0378-7206(01)00143-4

Liao, Z., \& Cheung, M. T. (2002). Internet-based e-banking and consumer attitudes: An empirical study. Information \& Management, 39(4), 283-295. doi:10.1016/S0378-7206(01)00097-0

Liébana-Cabanillas, F., Muñoz-Leiva, F., \& Rejón-Guardia, F. (2013). The determinants of satisfaction with e-banking. Industrial Management \& Data Systems, 113(5), 750-767. doi:10.1108/02635571311324188

Liébana-Cabanillas, F., Muñoz-Leiva, F., Sánchez-Fernández, J., \& Viedma-del Jesús, M. I. (2016). The moderating effect of user experience on satisfaction with electronic banking: Empirical evidence from the Spanish case. Information Systems and e-Business Management, 14(1), 141-165. doi:10.1007/s10257-015-0277-4

Lu, Y., Wang, B., \& Lu, Y. (2019). Understanding key drivers of mooc satisfaction and continuance intention to use. Journal of Electronic Commerce Research, 20(2).

Luo, M. M., \& Chea, S. (2018). Cognitive appraisal of incident handling, affects, and post-adoption behaviors: A test of affective events theory. International Journal of Information Management, 40, 120-131. doi:10.1016/j. ijinfomgt.2018.01.014

Luo, X., Li, H., Zhang, J., \& Shim, J. P. (2010). Examining multi-dimensional trust and multi-faceted risk in initial acceptance of emerging technologies: An empirical study of mobile banking services. Decision Support Systems, 49(2), 222-234. doi:10.1016/j.dss.2010.02.008

Mahal, P. K. (2016). Influence of emotional intelligence on employee satisfaction: An empirical study of banking sector. Journal of Strategic Human Resource Management, 5(1). Advance online publication. doi:10.21863/ jshrm/2016.5.1.024

Marinkovic, V., \& Obradovic, V. (2015). Customers' emotional reactions in the banking industry. International Journal of Bank Marketing, 33(3), 243-260. doi:10.1108/IJBM-09-2013-0107 
Maslowska, E., Malthouse, E. C., \& Collinger, T. (2016). The customer engagement ecosystem. Journal of Marketing Management, 32(5-6), 469-501. doi:10.1080/0267257X.2015.1134628

Mattila, A. S., \& Enz, C. A. (2002). The role of emotions in service encounters. Journal of Service Research, 4(4), 268-277. doi:10.1177/1094670502004004004

Mbama, C. I., Ezepue, P., Alboul, L., \& Beer, M. (2018). Digital banking, customer experience and financial performance: UK bank managers' perceptions. Journal of Research in Interactive Marketing, 12(4), 432-451. doi:10.1108/JRIM-01-2018-0026

Montazemi, A. R., \& Qahri-Saremi, H. (2015). Factors affecting adoption of online banking: A meta-analytic structural equation modeling study. Information \& Management, 52(2), 210-226. doi:10.1016/j.im.2014.11.002

Nam, K., Baker, J., Ahmad, N., \& Goo, J. (2019). Determinants of writing positive and negative electronic wordof-mouth: Empirical evidence for two types of expectation confirmation. Decision Support Systems, 113168.

Namahoot, K., \& Laohavichien, T. (2015). An analysis of behavioral intention to use Thai internet banking with quality management and trust. Journal of Internet Banking and Commerce, 20(3).

Nami, M. (2009). E-banking Issues and challenges: ACIS International Conference on Software Engineering, Artificial Intelligences, Networking and Parallel. Distributed Computing (SNPD).

Okada, E. M. (2005). Justification effects on consumer choice of hedonic and utilitarian goods. JMR, Journal of Marketing Research, 42(1), 43-53. doi:10.1509/jmkr.42.1.43.56889

Oliver, R. L. (1977). Effect of expectation and disconfirmation on postexposure product evaluations: An alternative interpretation. The Journal of Applied Psychology, 62(4), 480-486. doi:10.1037/0021-9010.62.4.480

Oliver Richard, L. (1997). Satisfaction: A behavioral perspective on the consumer. New York, NY: IrwinMcGraw-Hill.

Ozkan-Tektas, O., \& Basgoze, P. (2017). Pre-recovery emotions and satisfaction: A moderated mediation model of service recovery and reputation in the banking sector. European Management Journal, 35(3), 388-395. doi:10.1016/j.emj.2016.06.010

Park, J., \& Ha, S. (2016). Co-creation of service recovery: Utilitarian and hedonic value and post-recovery responses. Journal of Retailing and Consumer Services, 28, 310-316. doi:10.1016/j.jretconser.2015.01.003

Parthasarathy, M., \& Bhattacherjee, A. (1998). Understanding post-adoption behavior in the context of online services. Information Systems Research, 9(4), 362-379. doi:10.1287/isre.9.4.362

Pikkarainen, T., Pikkarainen, K., Karjaluoto, H., \& Pahnila, S. (2004). Consumer acceptance of online banking: An extension of the technology acceptance model. Internet Research, 14(3), 224-235. doi:10.1108/10662240410542652

Pyun, C. S., Scruggs, L., \& Nam, K. (2002). Internet banking in the US, Japan and Europe. Multinational Business Review, 10(2), 73.

Reichheld, F. F. (2003). The one number you need to grow. Harvard Business Review, 81(12), 46-55. PMID: 14712543

Reydet, S., \& Carsana, L. (2017). The effect of digital design in retail banking on customers' commitment and loyalty: The mediating role of positive affect. Journal of Retailing and Consumer Services, 37, $132-138$. doi:10.1016/j.jretconser.2017.04.003

Rodrigues, L. F., Costa, C. J., \& Oliveira, A. (2016). Gamification: A framework for designing software in e-banking. Computers in Human Behavior, 62, 620-634. doi:10.1016/j.chb.2016.04.035

Rose, G. M., Meuter, M. L., \& Curran, J. M. (2005). On-line waiting: The role of download time and other important predictors on attitude toward e-retailers. Psychology and Marketing, 22(2), 127-151. doi:10.1002/ mar.20051

Roy, R., \& Ng, S. (2012). Regulatory focus and preference reversal between hedonic and utilitarian consumption. Journal of Consumer Behaviour, 11(1), 81-88. doi:10.1002/cb.371 
Ryan, G., \& Valverde, M. (2006). Waiting in line for online services: A qualitative study of the user's perspective. Information Systems Journal, 16(2), 181-211. doi:10.1111/j.1365-2575.2006.00214.x

Shaikh, A. A., \& Karjaluoto, H. (2015). Mobile banking adoption: A literature review. Telematics and Informatics, 32(1), 129-142. doi:10.1016/j.tele.2014.05.003

Sharma, S. K., \& Sharma, M. (2019). Examining the role of trust and quality dimensions in the actual usage of mobile banking services: An empirical investigation. International Journal of Information Management, 44, 65-75. doi:10.1016/j.ijinfomgt.2018.09.013

Sikdar, P., Kumar, A., \& Makkad, M. (2015). Online banking adoption: A factor validation and satisfaction causation study in the context of Indian banking customers. International Journal of Bank Marketing, 33(6), 760-785. doi:10.1108/JJBM-11-2014-0161

Springett, M. (2009). Evaluating cause and effect in user experience. Digital Creativity, 20(3), 197-204. doi:10.1080/14626260903083637

Steg, L., Perlaviciute, G., Van der Werff, E., \& Lurvink, J. (2014). The significance of hedonic values for environmentally relevant attitudes, preferences, and actions. Environment and Behavior, 46(2), 163-192. doi: $10.1177 / 0013916512454730$

Sun, Y., Liu, X., Chen, G., Hao, Y., \& Zhang, Z. J. (2020). How mood affects the stock market: Empirical evidence from microblogs. Information \& Management, 57(5), 103181. doi:10.1016/j.im.2019.103181

Sun, Y., Wu, L., Chen, R., Lin, K., \& Shang, R.-A. (2020). Enterprise Social Software Platforms and Team Improvisation. International Journal of Electronic Commerce, 24(3), 366-390. doi:10.1080/10864415.2020. 1767430

Sun, Y., Zhou, X., Jeyaraj, A., Shang, R.-A., \& Hu, F. (2019). The impact of enterprise social media platforms on knowledge sharing. Journal of Enterprise Information Management, 32(2), 233-250. doi:10.1108/JEIM10-2018-0232

Szopiński, T. S. (2016). Factors affecting the adoption of online banking in Poland. Journal of Business Research, 69(11), 4763-4768. doi:10.1016/j.jbusres.2016.04.027

Thagard, P. (2001). How to make decisions: coherence, emotion, and practical inference. Academic Press.

Thagard, P., \& Millgram, E. (1997). Inference to the best plan: A coherence theory of decision. In Goal-driven learning (pp. 439-454). MIT Press.

Tronvoll, B. (2011). Negative emotions and their effect on customer complaint behaviour. Journal of Service Management, 22(1), 111-134. doi:10.1108/09564231111106947

Turel, O. (2015). Quitting the use of a habituated hedonic information system: A theoretical model and empirical examination of Facebook users. European Journal of Information Systems, 24(4), 431-446. doi:10.1057/ ejis.2014.19

Van der Heijden, H. (2004). User acceptance of hedonic information systems. Management Information Systems Quarterly, 28(4), 695-704. doi:10.2307/25148660

Voss, K. E., Spangenberg, E. R., \& Grohmann, B. (2003). Measuring the hedonic and utilitarian dimensions of consumer attitude. JMR, Journal of Marketing Research, 40(3), 310-320. doi:10.1509/jmkr.40.3.310.19238

Wang, M., Cho, S., \& Denton, L. T. (2017). The Impact of Personalization and Compatibility with Past Experience in E-Banking Usage. International Journal of Bank Marketing, 35(1), 45-55. doi:10.1108/IJBM-04-2015-0046

Williams, M. D., Rana, N. P., \& Dwivedi, Y. K. (2015). The unified theory of acceptance and use of technology (UTAUT): A literature review. Journal of Enterprise Information Management, 28(3), 443-488. doi:10.1108/ JEIM-09-2014-0088

Wu, J., \& Lu, X. (2013). Effects of extrinsic and intrinsic motivators on using utilitarian, hedonic, and dualpurposed information systems: A meta-analysis. Journal of the Association for Information Systems, 14(3), 1. doi: $10.17705 / 1$ jais.00325 
Wu, L. (2013). The antecedents of customer satisfaction and its link to complaint intentions in online shopping: An integration of justice, technology, and trust. International Journal of Information Management, 33(1), 166-176. doi:10.1016/j.ijinfomgt.2012.09.001

Xu, D., Tang, S., \& Guttman, D. (2019). China's campaign-style Internet finance governance: Causes, effects, and lessons learned for new information-based approaches to governance. Computer Law \& Security Review, 35(1), 3-14. doi:10.1016/j.clsr.2018.11.002

Zaffar, M. A., Kumar, R. L., \& Zhao, K. (2019). Using agent-based modelling to investigate diffusion of mobile-based branchless banking services in a developing country. Decision Support Systems, 117, 62-74. doi:10.1016/j.dss.2018.10.015

Zhang, J. Q., Craciun, G., \& Shin, D. (2010). When does electronic word-of-mouth matter? A study of consumer product reviews. Journal of Business Research, 63(12), 1336-1341. doi:10.1016/j.jbusres.2009.12.011

Zhu, Y.-Q., \& Chen, H.-G. (2010). Uncertainty Avoidance As A Moderator To Service Fairness And Customer Satisfaction In Online Banking. Journal of International Management, 17, 77-95.

Wei-Hsi (Frank) Hung is Professor of Management Information Systems at National Chengchi University, Taiwan He holds a Ph.D. degree from University of Waikato, New Zealand. His research interests are in the areas of e-commerce, IS alignment, knowledge management, and supply chain management. His research papers appeared in journals such as Decision Support Systems, Communications of the Association for Information Systems, Industrial Marketing Management, Journal of Global Information Management, Journal of Computer Information Systems, Computers in Human Behavior, Technology Analysis \& Strategic Management, Telematics and Informatics, Internet Research, Pacific Asian Journal of Association for Information Systems, International Journal of Logistics Research and Applications, Journal of Information Management, Asia Pacific Management Review, Communications of the ICISA, International Journal of Web Portals, and Electronic Journal of Information Systems Evaluation.

Chih-Lang Tseng is a PhD student of the Department of Information Management at National Chung Cheng University. His research areas are in the information systems implementation, service quality, and e-commerce.

Fang-Kai Chang is assistant professor at the Department of Business Administration in the Fang Chia University in Taiwan. His research interests are in the areas of cross-border e-commerce, and IT-enabled service, and has published in various international journals.

Chin-Fu Ho is professor at the Department of Multimedia Design in the Takming University of Science and Technology in Taiwan. His research focuses on electronic commerce, supply-chain management, knowledge management, and information and communication technology implementation. His research papers appeared in journals such as International Journal of Operations and Production Management, Engineering Costs and Production Economics, Industrial Management \& Data Systems, International Journal of Electronic Commerce, Journal of the Chinese Institute of Industrial Engineers, International Journal of Production Research, International Journal of Logistics: Research and Applications, IEEE Transactions on Engineering Management, International Journal of Logistics Research and Applications, Journal of Computer Information Systems, and Decision Support Systems. 